of adipokines. Many studies have shown increasing leptin level and reducing adiponectin level in patients with rheumatoid arthritis (RA) compared with healthy ones. On the other hand the roles of adipokines in pathogenesis of autoimmune disorders are still controversial due to their both pro-inflammatory and anti-inflammatory effects.

Objectives: The aim of this study was to evaluate adipokine levels in patients with RA and to assess their association with the activity of inflammatory process Methods: The study included 62 patients with RA and 35 practically healthy sex and age matched persons of control group. The diagnosis of RA was established according to the ACR 2010. Erythrocyte sedimentation rate (ESR), C-reactive protein (CRP) were used to assess inflammation. Disease activity and functional impairment were evaluated using the Disease Activity Score (DAS28). Serum leptin and adiponectin levels were studied by immunoassay using standard sets (DRG", Germany and "Orgenium", Finland). Results are expressed as mean \pm standard error of the mean. Spearman's $r$ was used to calculate correlations between markers of disease activity (ESR, CRP, DAS28) and serum adipokine levels. A p value $<0.05$ was considered statistically significant for all tests

Results: It was found that the mean value of leptin and adiponectin levels were $20.7 \pm 12.3 \mathrm{ng} / \mathrm{ml}$ and $2.47 \pm 1.34 \mathrm{ng} / \mathrm{ml}$ respectively in patients with RA and 6.47 $\pm 3.17 \mathrm{ng} / \mathrm{ml}$ and $4.21 \pm 1.4 \mathrm{ng} / \mathrm{ml}$ respectively in the control group. Thus, the leptin level in patients with RA was 3.2 times higher, and adiponectin level was 1.7 times lower than in healthy individuals. Levels of adipokins were associated with the activity of the inflammatory process. Thus, serum concentration of leptin level was increased $(r=0.33$ and $r=0.35)$ and adiponectin level was decreased $(r=-0.25$ and $r=-0.24$ ) with the increasing of ESR and CRP. Similar patterns were observed for the integral index of RA activity DAS28. In particular, DAS28 was 1.6 times higher in subjects with leptin levels above $44.7 \pm 9.4 \mathrm{ng} / \mathrm{ml}$ than in the group of patients with leptin levels below $44.7 \pm 9.4 \mathrm{ng} / \mathrm{ml}$. The correlation analysis has also confirmed the close association between the leptin and adiponectin levels with DAS28 activity index ( $r=0.37$ and $r=-0.28$, respectively).

Conclusions: Disadipokineemia in patients with RA is characterised by the increasing of serum leptin level and the decreasing of serum adiponectin level and is closely related to the activity of the inflammatory process.

Disclosure of Interest: None declared

DOI: 10.1136/annrheumdis-2018-eular.5343

\section{AB0131 RHEUMATOID FACTOR IS DETECTED ON CIRCULATING EXTRACELLULAR VESICLES IN A SUBPOPULATION OF RHEUMATOID ARTHRITISPATIENTS WITH A MORE SEVERE DISEASE PHENOTYPE}

O. Arntz, B. Pieters, R. Thurlings, P.V.D. Kraan, F.V.D. Loo. Experimental Rheumatology, Dept. of Rheumatology, Radboud University Medical Center, Nijmegen, Netherlands

Background: Extracellular vesicles (EVs) play a role in cell-cell communication and contain numerous signalling molecules inside and on their cell membrane. Although their function remains to be elucidated, evidence accumulates that EVs play a regulatory role in immunity during health and disease. They contain numerous proteins, lipids, RNA, DNA and sometimes cell organelles such as mitochondria. In a recent study was shown that Immunoglobuline M-Rheumatoid factor (IgM-RF) is present on milk derived exosomes. ${ }^{1}$ High IgM-RF levels in Rheumatoid Arthritis (RA) predict a more severe disease and comorbidities, probably due to their involvement in immune complex formation and activation of complement (crucial mediators of the effector phase of inflammation in the pathogenesis of RA).

Objectives: In this study we investigate whether $\mathrm{RF}+\mathrm{EV}$ s are detectable in the circulation of RA patients and if this relates to parameters of disease activity.

Methods: EVs were isolated from platelet-free plasma of 38 RA patients and from age and sex-matched 24 healthy controls $(\mathrm{HC})$ by size exclusion chromatography. EV markers (tetraspanins) were detected by Western blot and miRNA content by RT-qPCR. Particle size and concentration were measured by electron microscopy and nanosight tracking analysis. Protein concentration was determined by micro-BCA. RF levels were measured using a commercial ELISA. The percentage of RF $+E V s$ was determined by measuring bound and unbound PHK labelled EVs to Protein $L$ magnetic beads in a fluorometer.

Results: Mean EV particle size, concentration and protein content were not different between RA patients and HC. 27 of the 38 RA patients were classified as RF+ $(>10 \mathrm{lU} / \mathrm{ml})$ and of the clinical parameters studied only their erythrocyte sedimentation rate (ESR) was higher (31 vs $14 \mathrm{~mm} / \mathrm{hr}$ ). In $14 \mathrm{RF}$ +patients, RF was detectable on a small portion of EVs not exceeding $4 \%$ of the total number of circulating EVs. Interestingly, RA patients with RF + EVs showed higher disease activity as assessed by patient global health assessment using a visual analogue scale (63 vs 31), blood C-reactive protein (22 vs $9 \mathrm{mg} / \mathrm{L}$ ) and ESR (43 vs $19 \mathrm{~mm} / \mathrm{hr}$ ) levels, than RA patients with undetectable RF + EVs.

Conclusions: This study shows for the first time that in a subpopulation of RA patients RF is present on EVs, which might originate from their B-cells. The higher disease activity in RA patients expressing RF on their EVs suggests that RF +EVs are involved in RA pathogenesis.

\section{REFERENCE:}

[1] Yang M, et al. Comparative proteomic analysis ofmilk-derived exosomes in human and bovine colostrumandmature milk samples by iTRAQ-coupled LC-MS/MS. Food Research International 2017;92(2017):17-25.

Disclosure of Interest: None declared

DOI: 10.1136/annrheumdis-2018-eular.5373

\section{AB0132 INFLAMMATION IN MICE}

S.M. Jung ${ }^{1}$, J. Lee ${ }^{2}$, S.Y. Baek ${ }^{2}$, J. Lee ${ }^{2}$, S.G. Jang ${ }^{2}$, S.-M. Hong ${ }^{2}$, D. Kim¹ , H. W. Kim ${ }^{3}$, S.-K. Kwok ${ }^{2} .{ }^{1}$ Internal Medicine, Yonsei University College of Medicine; ${ }^{2}$ Internal Medicine, College of Medicine, The Catholic University of Korea, Seoul; ${ }^{3}$ Internal Medicine, Seoul National University Bundang Hospital, Bundang, Korea, Republic of Ireland

Background: Fraxinellone is isolated from Dictamnus dasycarpus, a traditiona herbal medicine that attenuates inflammatory conditions. ${ }^{1,2}$ Recent studies have suggested that fraxinellone has a potential therapeutic effect in animal models with inflammatory diseases. ${ }^{3-5}$

Objectives: We aimed to evaluate the therapeutic effect of fraxinellone on inflammatory arthritis and identify the underlying mechanisms.

Methods: Fraxinellone $(7.5 \mathrm{mg} / \mathrm{kg})$ or a vehicle control was injected into mice with collagen-induced arthritis (CIA). The severity of arthritis was evaluated clinically and histologically. The differentiation of CD4 +T cells and CD19+B cells was investigated in the presence of fraxinellone. Osteoclastogenesis after fraxinellone treatment was evaluated by staining with tartrate-resistant acid phosphatase (TRAP) and by measuring the mRNA levels of osteoclastogenesis-related genes. Results: Fraxinellone attenuated the clinical and histologic features of inflammatory arthritis in CIA mice. Fraxinellone suppressed the expression of interleukin17, and T helper 17 cell-related transcription factors (ROR $\gamma$ t and phosphorylated STAT3) in CD4 + T cells. CD19 +B cells showed lower expression of activationinduced cytidine deaminase (AID) and Blimp-1 after treatment with fraxinellone. The formation of TRAP-positive cells and the expression of osteoclastogenesisrelated markers were reduced in the presence of fraxinellone. Inhibition of interleukin-17 and osteoclastogenesis was also observed in experiments using human peripheral mononuclear cells.

Conclusions: Fraxinellone alleviated synovial inflammation and osteoclastogenesis in mice. The therapeutic effect of fraxinellone was associated with the inhibition of cellular differentiation and activation. The data suggests that fraxinellone could be a novel treatment for inflammatory arthritis, including rheumatoid arthritis.

\section{REFERENCES}

[1] Jiang Y, Li SP, Chang HT, Wang YT, Tu PF. Pressurized liquid extraction followed by high-performance liquid chromatography for determination of seven active compounds in Cortex Dictamni. Journal of chromatography A 2006;1108:268-272.

[2] Sun J, Wang X, Wang P, Li L, Qu W, Liang J. Antimicrobial, antioxidant and cytotoxic properties of essential oil from Dictamnus angustifolius. Journal of ethnopharmacology 2015;159:296-300.

[3] Wu XF, Ouyang ZJ, Feng LL, Chen G, Guo WJ, Shen Y, Wu XD, Sun Y, $\mathrm{Xu} Q$. Suppression of NF-kappaB signaling and NLRP3 inflammasome activation in macrophages is responsible for the amelioration of experimental murine colitis by the natural compound fraxinellone. Toxicology and applied pharmacology 2014;281:146-156.

[4] Sun Y, Qin Y, Gong FY, Wu XF, Hua ZC, Chen T, Xu Q. Selective triggering of apoptosis of concanavalin A-activated $T$ cells by fraxinellone for the treatment of T-cell-dependent hepatitis in mice. Biochemical pharmacology 2009;77:1717-1724.

[5] Jiang S, Nakano Y, Rahman MA, Yatsuzuka R, Kamei C. Effects of a Dictamnus dasycarpus T. extract on allergic models in mice. Bioscience, bio technology, and biochemistry 2008;72:660-665.

Acknowledgements: This research was supported by the Catholic Medical Centre Research Foundation made in the program year of 2014.

Disclosure of Interest: None declared

DOI: 10.1136/annrheumdis-2018-eular.6284 